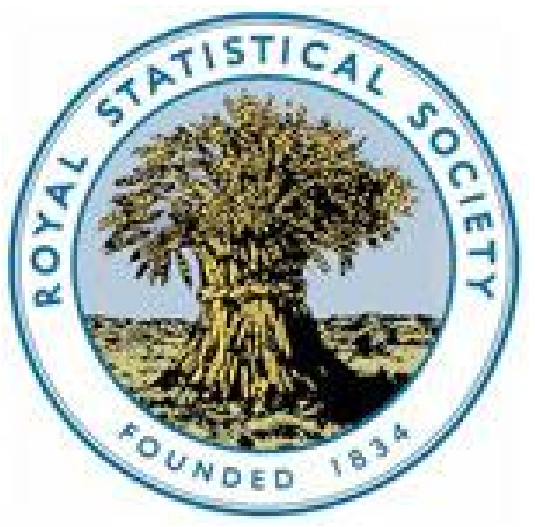

\title{
WILEY
}

Old Age Pensions in the United Kingdom

Author(s): N. A. H.

Source: Journal of the Royal Statistical Society, Vol. 74, No. 1 (Dec., 1910), pp. 71-73

Published by: Wiley for the Royal Statistical Society

Stable URL: http://www.jstor.org/stable/2339982

Accessed: 27-06-2016 15:56 UTC

Your use of the JSTOR archive indicates your acceptance of the Terms \& Conditions of Use, available at

http://about.jstor.org/terms

JSTOR is a not-for-profit service that helps scholars, researchers, and students discover, use, and build upon a wide range of content in a trusted digital archive. We use information technology and tools to increase productivity and facilitate new forms of scholarship. For more information about JSTOR, please contact support@jstor.org.

Royal Statistical Society, Wiley are collaborating with JSTOR to digitize, preserve and extend access to Journal of the Royal Statistical Society 


\section{III.-Old Age Pensions in the United Kingdom.}

A RECEnT Report issued by the Postmaster-General shows the number and value of the old age pensions in force and paid in the several divisions of the United Kingdom during the first three months of 1909, and during the year ending March 31 last. These figures possess considerable statistical interest in connection with the estimated numbers of persons aged upwards of 70 years in each of those separate divisions, and with the relative numbers of pensions paid.

In order to appreciate the true import of this official return it is necessary, in the first place, to estimate on the basis of census returns the number of persons aged upwards of 70 years in the several divisions of the United Kingdom. Such estimates are necessarily based on the assumption that the proportion of the several populations living at those ages is now the same as those which prevailed at the last census, in 1901. That this is a probably sound hypothesis is supported by the fact that the proportion in England and Wales of persons aged 70 years and upwards, to the total population at all ages was practically almost identical at each of the four censuses in 1871-1901. In Ireland, moreover, the proportion to total population of persons aged over 70 in 1901 was very slightly below that which prevailed at each of the two previous censuses in 1881 and 1891.

The following table shows the Registrar-General's estimate of the population of each division of the United Kingdom in the middle of this year; the percentage of the several populations aged upwards of 70 years at the last census, in 1901; the estimated numbers of these populations now living at these ages; the respective numbers of old age pensions in force on March 31 last; and the relative percentage of pensions to the estimated numbers of persons aged 70 years and upwards in each division of the United Kingdom :-

\begin{tabular}{|c|c|c|c|c|c|}
\hline $\begin{array}{c}\text { Division } \\
\text { of the } \\
\text { United Kingdom. }\end{array}$ & $\begin{array}{c}\text { Estimated } \\
\text { population } \\
\text { in } \\
\text { middle of } 1910 .\end{array}$ & $\begin{array}{c}\text { Percentage } \\
\text { of } \\
\text { persons } \\
\text { iged 70 years } \\
\text { and upwrards } \\
\text { enumerated } \\
\text { in 1901. }\end{array}$ & $\begin{array}{c}\text { Tstinuited } \\
\text { number } \\
\text { of persons } \\
\text { aged upwards } \\
\text { of 70 yetrs } \\
\text { in middide of } \\
1910 .\end{array}$ & $\begin{array}{c}\text { Old age } \\
\text { pensions } \\
\text { in } \\
\text { force } \\
\text { on } \\
\text { March } 31, \\
1910 .\end{array}$ & $\begin{array}{c}\text { Percentage } \\
\text { of } \\
\text { pensions } \\
\text { to estimated } \\
\text { persons } \\
\text { aged } \\
\text { over } 70 .\end{array}$ \\
\hline $\begin{array}{l}\text { England and Wales } \\
\text { Scotland } \\
\text { Ireland }\end{array}$ & $\begin{array}{r}36,169,150 \\
4,929,251 \\
4,371,133\end{array}$ & $\begin{array}{l}2 \cdot 73 \\
2 \cdot 90 \\
4 \cdot 20\end{array}$ & $\begin{array}{l}987,416 \\
142,948 \\
183,588\end{array}$ & $\begin{array}{r}441,489 \\
76,889 \\
180,974\end{array}$ & $\begin{array}{l}44 \cdot 7 \\
53 \cdot 8 \\
98 \cdot 6\end{array}$ \\
\hline
\end{tabular}

From the above table it appears that 45 per cent. of the persons aged upwards of 70 years were in receipt of old age pensions in England and Wales on March 31 last; and that in Scotland the proportion was 54 per cent. These percentages may probably be accepted as approximately indicating the relative poverty of the population of England and Wales and of Scotland. With regard to the fact that in Ireland very nearly 99 per cent. of the estimated number of persons aged upwards of 70 years were on March 31 
last in receipt of old age pensions, it seems more than difficult to accept the same explanation.

It is scarcely necessary to point out that under the provisions of the Old Age Pension Act (1908) either receipt of poor-law relief after the first day of January, 1908, or the possession of "yearly means" exceeding $3 \mathrm{I} l$. ros. was declared a disqualification for the receipt of an old age pension. No satisfactory basis exists for estimating the proportion of persons over 70 years of age, in the three divisions of the United Kingdom, possessing "yearly means" exceeding $3 \mathrm{r} l$. ros. As regards, however, the proportion of persons aged over 70 years in receipt of poor law relief, Local Government Board returns afford what may be accepted as trustworthy information. Mr. Charles Booth's valuable pamphlet on "Old Age Pensions and the Aged Poor" contains a useful table based, in 1899, on a "twelve months' count," showing that in England and Wales no less than $35^{\circ} 5$ per cent. of the population aged upwards of 70 years were in receipt of poor law relief, including 19.4 per cent. in receipt of in-door and $26 \cdot 1$ per cent. of out-door relief. It may therefore fairly be assumed that at least one-third of the population at these ages in England and Wales are at present disqualified for pensions by receipt of poor law relief since January 1, 1908. The proportion of poor law relief to population at all ages varies but slightly in the several divisions of the United Kingdom, and although no information similar to that compiled for England and Wales by Mr. Charles Booth is available, it may fairly be assumed that at least a third of the persons aged over 70 years in both Scotland and Ireland have received poor law relief since the beginning of 1908. Deducting, therefore, this third from the estimated numbers of persons now living at these ages, it may be calculated that of the remaining two-thirds 67 per cent. in England and Wales and 8I per cent. in Scotland were in receipt of old age pensions on March 31 last. Thus it appears that, apart from relief disqualifications, 33 per cent. of persons aged upwards of 70 years in England and Wales and 19 per cent. in Scotland are not in receipt of pensions, owing probably, in the main, to the possession of "yearly means" exceeding $3 \mathrm{I} l$. ros. In Ireland, however, the number of old age pensioners at the end of last March exceeded by 48 per cent. the total estimated population aged over 70 years, after deduction of the third presumed to have received poor-law relief since January 1, 1908, and without any deduction for those possessed of "yearly means" exceeding $3 \mathrm{r}$ l. ros. This startling excess of old age pensioners in Ireland may be due (1) partly to overstatement of age; (2) partly to disregard of disqualification by receipt of poor-law relief; and (3) partly by understatement of "yearly means." The marked excess of pensions allotted in Ireland attracted considerable notice in Parliament and in the press last year, and a special inquiry was ordered, with a view to the withdrawal of unauthorised pensions. No report on the result of this inquiry appears, however, to have been published, and it is not without interest to note that the amount paid for old age 
pensions in Ireland during the year ending with March last was $2,321,729 l$., which exceeded by 106,225l. four times the amount paid during the first quarter of 1909 , and was considerably more than double the amount paid during the year ending March 31 last in Scotland, the total population of which is estimated to exceed that of Ireland by more than half a million. A report of the result of the above mentioned official inquiry concerning the marked excess of old age pensions in Ireland compared with those in the other divisions of the United Kingdom, would be full of interest from a statistical point of view.

N.A.H.

\section{IV.-Population and Costs in Relation to City Management. By C. Ashmore Baker.}

WHILST preparing the figures given in a recently published volume of tables relating to municipal money matters, ${ }^{1}$ it occurred to the writer that it might be of interest to ascertain if anything in the way of a direct relation exists between population and the cost of City management. This inquiry is of particular interest at the present time in view of the movement which is taking place in several of our larger cities towards the absorption of their smaller immediate neighbours. Apart from any advantages to be derived from uniformity of administration, which may be claimed for such a policy, the question of cost is an important one, and it has frequently been claimed that the aggregation of administrative areas tends to a general reduction in administrative costs.

A comparison of the averages for the four groups of towns into which the tables are divided indicates, as a matter of fact, with some exceptions, a slight general increase in the cost of any given service per head of population as the sizes of the towns increase. The most striking feature shown by a comparison of the figures is, however, the extremely small influence which the mere population of a town exerts on the per capita cost of its public services. Thus the cost per head for education for the group of urban district councils, which are their own education authorities, is only 12 per cent. lower than that of the group of county boroughs, notwithstanding the fact that the average populations of the two groups is as 36,000 to 137,000 , or as I to nearly 4. The total revenue also of the former group bears a similar relation to that of the latter.

In the case of several services, such for instance as salaries and superannuation, street maintenance, public lighting and sewerage, there appears to be little or no direct relation between per capita cost and population. Indeed, as regards the three last, the uniformity

1 Rates, being the revenue and expenditure of boroughs and urban district councils of 10,000 or more inhubitants (England and Wales). Analysed and compared by C. Ashmore Baker. London: P. S. King and Son. 